\title{
Publishing a Special Issue of Reports from the volcano observatories in Latin America
}

Este artículo está disponible en español: https://doi.org/10.30909/vol.04.S1.ivi [PDF ES].

Peer-reviewed publications are the most common way of sharing scientific knowledge internationally. Volcanica is the only fully diamond open access journal in volcanology, publishing peer-reviewed articles without costs to authors or readers. As part of our wider journal mission, Volcanica also aims to address some of the biggest barriers in research publication and to increase accessibility to published, written research outputs. In this Editorial, we discuss Volcanica's latest venture: to publish a complete Special Issue of Reports-one of our flagship publication formats designed specifically for cutting edge, direct observations from volcanoes* -and to do so in both English and Spanish languages.

In this Special Issue we have worked with the Asociación Latinoamericana de Volcanología (ALVO) ${ }^{\dagger}$ to publish peer-reviewed Reports written by representatives, managers, scientists, and researchers from the volcano observatories in all ten of the Latin American countries in which there is currently an official volcano monitoring program. From South to North, these are: Chile, Argentina, Peru, Ecuador, Colombia, Costa Rica, Nicaragua, El Salvador, Guatemala, and Mexico (Figure 1). The Reports are preceded by a preface written by ALVO's representatives [Forte et al. 2021, this issue].

This initiative and Special Issue is motivated by the need-identified by Latin American volcanologists in ALVO and beyondfor a reference volume detailing the volcano monitoring, volcano observatory, and volcano management activities in their region. This has also been a great opportunity to bring all Latin American volcano observatories together to collaborate on a common project on a regional scale. It was important to these stakeholders that such a reference publication should be easily and freely accessible to their respective communities, to the volcanological community more broadly, and to the in-

*https://www. jvolcanica.org/ojs/index.php/volcanica/about/ submissions

${ }^{t}$ https://vhub.org/groups/alvo/overview_english terested general public.

A key part of 'accessible' in this context is associated with the language barrier of modern research publication, namely that the majority of research is published in English. Both Volcanica and ALVO noted that the linguistic Anglo-centrism of volcanology research is cast against the observation that English is not the first language for many communities living in areas of active volcanism [e.g. Farquharson and Wadsworth 2018]. Language is a core part of the documentation of primary observations of volcanic eruptions as well as the dissemination of volcanology research results worldwide. Taken together, observations from eruptions, results and lessons from volcano monitoring efforts, and volcanology research, all feed into the communication chain that results

in improvements to the responses when there is a volcanic eruption. There are key advantages to having a single international language in which research is written and shared. But there are also key limitations associated with accessibility of research to a broad group of people. It is perhaps more important in volcanology than in some other disciplines simply because the research into volcanic activity can very often be associated with a particular region or place in which many people live with active volcanism and hence where volcanic risk reduction strategies need to be improved. Therefore, this Special Issue is published in both Spanish - the common official language of the countries in Latin America here represented-and English. The English version was reviewed by at least two international peers and, once accepted, the Spanish translation was verified by bilingual ALVO members and Volcanica editors. This endeavour therefore extends our existing and widely used dual-language abstract option at Volcanica, which has been a catalyst 
Figure 1: [Previous page] An 'exploded view' of the 10 Latin American countries for which there is currently an official volcano monitoring program and for which a Report is published in this Special Issue. MX: Mexico; GU: Guatemala; NI: Nicaragua; ES: El Salvador; PM: Panama; CR: Costa Rica; CO: Colombia; EC: Ecuador; PE: Peru; BO: Bolivia; $\mathrm{CH}$ : Chile; and AR: Argentina. The numbers in red and grey refer to the total number of active and monitored volcanoes in the country, respectively.

for full dual-language publication in this Special Issue. We posit that language barriers to volcanology research need careful consideration moving forward. While this Special Issue shows us just how much additional effort is involved in coordinating multi-lingual publication, we hope that it goes some way to increasing accessibility to the information published here.

Volcanica's Report format is one designed with volcano observatory staff in mind. In our first Report published in 2018, members of the Instituto Geofisico de la Escuela Politécnica Nacional, Ecuador, worked with colleagues from Pennsylvania State University, U.S.A., and the Universidad Central del Ecuador, Ecuador, to document recent eruption activity from Fernandina and Sierra Negra volcanoes [Vasconez et al. 2018]. These Report articles aim to be short-format and are publications that can simply document observations, activity, monitoring advances in the field, methods, trialled evacuation procedures, etc. While we do not mandate that this article type must come from volcano observatory staff, we hope that it is appealing to members of monitoring organisations, as a primary, peer-reviewed mechanism to disseminate best-practice and front-line information from active volcanic areas. For these reasons, this format was the ideal forum for a Special Issue from volcano observatory staff, members, and affiliates in Latin America, and this made it easy for Volcanica to pursue this endeavour here-published with ALVO.

Publishing a dual-language issue places substantial additional work burdens on both the content authors and the editorial board and technical teams at a journal. In addition to the usual challenges in peer review and article production, challenges are associated with language translation verification, ensuring formatting and contextual consistency between Reports across the Special Issues, typesetting and copyediting in multiple languages. This Special Issue therefore involves a huge undertaking by a large group of people. Not only have observatory staff members cooperated and provided articles about their institute activities and volcanoes, they have sometimes collaborated across national institutes to provide a single voice for a given Latin American country. We note that there is a single exception, such that here we publish two articles associated with the monitoring of Peru's volcanic activity both within the
Peruvian national jurisdiction. In all cases, the members of these observatories collaborated with our editorial committee, editorial board, ALVO, and with our reviewers and technical teams, all while continuing their monitoring, teaching, technical duties and outreach activities.

We now take the opportunity to warmly acknowledge the following groups of people who have contributed to this issue.

- Our special guest editor, Pablo Forte, who was the initiator of this special issue and the bond between the observatory communities and the Volcanica editorial board.

- The reviewers who critically commented and corrected the Reports (in alphabetical order): Jenni Barclay, François Beauducel, Sonia Calvari, Robin Campion, Amy Donovan, Dolors Ferrés, Anthony Finizola, Nico Fournier, Christopher Harpel, Michael Heap, Alexandra Kushnir, John Lyons, Patricia Mothes, J. Maarten de Moor, Christina Neal, Natalie Ortiz, Jose Luis Palma, Matthew Patrick, Mike Poland, Dmitri Rouwet, Bill Rose, Pablo Samaniego, José Viramonte, Glyn Williams-Jones, and Heather Wright.

- The members of ALVO who participated in coordinating this issue and verified the Spanish versions of each Report: Pablo Forte, Lizette Rodríguez, Mariana Patricia Jácome Paz, Lizeth Caballero García, Yemerith Alpízar Segura, Emilce Bustos, Constanza Perales Moya, Eveling Espinoza, Silvia Vallejo, Mariano Agusto, Laura Vélez, María Clara Lamberti, Jorge Romero, Daniel Bertín, Rosario Vázquez, and Lucía Dominguez.

- The technical and section editors of Volcanica who copyedited, proofread, and typeset the Reports: Jamie Farquharson, Fabian Wadsworth, Alexandra Kushnir, Michael Heap, Elena Maters, Ery Hughes, Claire Harnett, and Gareth N. Fabbro. We also acknowledge the wider Volcanica editorial committee and board for their support of this endeavour.

- The 84 authors who wrote the Reports (in alphabetical order): Rigoberto Aguilar Contreras, Mariano Agusto, Miguel Alatorre, Yemerith Alpízar Segura, Guillermo E. Alvarado, Álvaro Amigo, Daniel Andrade, Mario Angarita, Yanet Antayhua Vera, Fredy Apaza Choquehuayta, Raúl Arámbula, Peter D. Argueta Ordoñez, Geoffroy Avard, Gabriela Badi, Henriette Bakkar, Emilce Bustos, Lizeth Caballero García, Marta Lucía Calvache Velasco, Lucia Capra, Monserrat Cascante, Rodolfo Castro, Ricky Centeno, David Chavarría, Gustavo A.Chigna Marroquin, Carla M. F. Chun Quinillo, Jorge Concha, Francisco Córdoba, Gloria Patricia Cortés Jiménez, John Cruz, Luis Cruz Mamani, J. Maarten de Moor, José Del Carpio, Ramón 
Espinasa-Pereña, Eveling Espinoza, Pablo Forte, Sébastián García, Diego Mauricio Gómez Martinez, Dulce. M. E. González Domínguez, Eduardo Gutiérrez, Ariadna Hernández-Oscoy, Silvana Hidalgo, Martha Ibarra, Mariana Patricia Jácome Paz, Francisco J. Juárez Cacao, Ivonne Lazarte, Cristian Mauricio López Vélez, Luisa Macedo, Roger Machacca, Alan Malpartida, Maria Martínez, Dodanis Matus, Elvis Mendoza, Edgar R. Mérida Boogher, María Luisa Monsalve Bustamante, Mauricio M. Mora, Patricia Mothes, Cyril Muller, Martha Navarro, Teresita Olivares, Mayra Ortega Gonzáles, Javier Pacheco, Constanza Perales Moya, Nino Puma, Patricio Ramón, Silvia Ramos, Marco Rivera, Amilcar E. Roca Palma, Lizzette Rodríguez, Paulo Ruiz, José Armando Saballos, Santiago Santamaría, Katrin Sieron, Gerardo J. Soto, Edu Taipe Maquarhua, Hernando Tavera, Virginia Tenorio, José Torres, Silvia Vallejo, Katherine Vargas, Francisco J. Vásconez, Lizbeth Velarde, Javier Vilca, and Hugo Yepes.

Finally, in this Editorial, we conclude that the Reports contained within this Special Issue represent (1) an up-to-date state-of-the-art for the monitoring capacity, monitoring activities, and outstanding challenges faced by volcano observatories in Latin America; and (2) an attempt to address issues of accessibility of published information to a wide readership, including those for whom the information is perhaps most pertinent. Looking forward, Volcanica is committed to both exploring and deploying publication strategies that enable accessibility to be a core part of journal responsibility in research communities. We close by suggesting that grass-roots community-led journals such as Volcanica have the built-in flexibility required to nimbly respond to creative ideas put forward by the research communities they serve, and as such, we continue to welcome new suggestions for improving our publication offering for volcanology and related disciplines.

Yours volcanically,

- Oryaëlle Chevrel ${ }^{\star \alpha}$, Fabian B. Wadsworth ${ }^{\beta}$, Jamie I. Farquharson $\gamma$, Alexandra R. L. Kushnir ${ }^{\delta}$, Michael J. Heap ${ }^{\delta, \epsilon}$, Rebecca Williams ${ }^{\zeta}$, Pierre Delmelle ${ }^{\eta}$, Ben Kennedy ${ }^{\theta}$

"Give me silence, water, hope.

Give me struggle, iron, volcanoes.”

- Pablo Neruda

\section{Affiliations}

* Corresponding author: oryaelle.chevrel@ird.fr $\alpha$ Laboratoire Magmas et Volcans, Université Clermont Auvergne, CNRS, IRD, OPGC, 63000 Clermont-Ferrand, France.

$\beta$ Earth Sciences, Durham University, Durham, DH1 3LE, U.K.

$\gamma$ Independent, Edinburgh, U.K.

$\delta$ Université de Strasbourg, CNRS, Institut Terre et Environnement de Strasbourg, UMR 7063, 5 rue Descartes, Strasbourg F-67084, France.

$\epsilon$ Institut Universitaire de France, Paris, France.

$\zeta$ Department of Geography, Geology and Environment, University of Hull, Hull, HU6 7RX, U.K.

$\eta$ Environmental Sciences, Earth and Life Institute, UCLouvain, Croix du sud 2, bte L7.05.10, 1348 Louvainla-Neuve, Belgium.

$\theta$ Earth and Environment, University of Canterbury, Private Bag 4800, Christchurch 8140, New Zealand.

\section{COPYRIGHT NOTICE}

(C) The Author(s) 2021. This article is distributed under the terms of the Creative Commons Attribution 4.0 International License, which permits unrestricted use, distribution, and reproduction in any medium, provided you give appropriate credit to the original author(s) and the source, provide a link to the Creative Commons license, and indicate if changes were made.

\section{REFERENCES}

Farquharson, J. and F. Wadsworth (2018). "Introducing Volcanica: The first diamond open-access journal for volcanology". Volcanica 1 (1), pp. i-ix. Dor: 10.30909/ vol.01.01.i-ix.

Forte, P., L. Rodríguez, M. P. J. Paz, L. C. García, Y. A. Segura, E. Bustos, C. P. Moya, E. Espinoza, S. Vallejo, and M. Agusto (2021). "Volcano monitoring in Latin America: taking a step forward". Volcanica 4 (S1), pp. vii-xxxiii. DOI: 10.30909/vol.04.S1.viixxxiii.

Vasconez, F., P. Ramón, S. Hernandez, S. Hidalgo, B. Bernard, M. Ruiz, A. Alvarado, P. L. Femina, and G. Ruiz (2018). "The different characteristics of the recent eruptions of Fernandina and Sierra Negra volcanoes (Galápagos, Ecuador)". Volcanica 1 (2), pp. 127133. DoI: $10.30909 / \mathrm{vol} .01 .02 .127133$. 